\title{
The Need of Law
}

\section{Zárate JF*}

Department of Criminal Law, University of Guadalajara, Mexico

\section{Opinion}

Volume 3 Issue 4

Received Date: November 12, 2020

Published Date: November 24, 2020

DOI: $10.23880 /$ abca- 16000150 of meeting all the social expectations of vindication. The democratic forms left the privileges of the upper classes untouched; with a different mode of production, there were still few rich and many poor. Inexplicably in our eyes, the start of World War I meant for millions (especially in Europe) the possibility of changing things. When an unjust peace ended the conflict and left everything as it was before and even worse, the eyes of the masses turned towards the nascent Soviet Union that propagandistically, it boasted of being the workers' government. The fanatical appeal and rejection of communism, coupled with disillusionment with a weak and ineffective democratic system, led to a clash between extremisms that inevitably led to World War II. This and the subsequent Cold War led successively to show the failure of fascism and communism. The end of the ideological and political confrontation between the United States and the former Soviet Union with the fall of the latter showed the world the triumph of a capitalist and democratic system that quickly showed its inability to solve the enormous problems of a growing population in the midst of poverty, injustice, and pollution and it was then that an alternative phenomenon (because it was not new) to all the previous ones grew that can make a bad mix of all of them: the so-called populism, whose characteristics are as ambiguous as its protagonists. Populism can be left-wing, right-wing, pretend to be democratic and authoritarian, call itself libertarian and actually be despotic, finding false enemies who do evils that itself will finally not solve.

Its method is lies and deception, but of course, shown emphatically and convincingly.

We can see the first populist demonstrations mainly in South America, but they have spread like a disease to countries that seemed vaccinated against it: North America and Europe. Newly minted populists, with fascist or communist overtones, without being any of them in their original form, 
offer the great masses easy solutions to the terrible evils that afflict them, amidst lying and strident promises. And worst of all, people follow them, believe them, vote for them. As long as the fallacy of this policy is shown, which can be years or decades (as the lie of fascism and communism was shown), it is doing enormous damage to democracy (the least bad of the systems, paraphrasing Churchill).

Now, how to stop the populist avalanche? There are no easy solutions, but I dare to propose one: unrestricted respect for the law. Although it is true that in the long run, every populist regime ends up changing the legal system to its advantage (in the case of Venezuela or Cuba), in countries where populism already governs or is about to govern, there are strong legal structures that contain sufficient legal defenses to stop populist attacks. The United States, France, Austria, Holland, and other nations under threat of populism that can modify their laws to make the change irreversible, still have the legal instruments to prevent it. Its legislation (not its daily life) is egalitarian, fair, and democratic, and the fight against populism will be an everyday battle, as it was before against segregation or for the vote.

There must be in education, that is, in school teaching, an emphasis in their curricula to respect the law; should that respect become a personal habit; And if in someone's closest circle everything is respect for the rules, that extends to the community and the entire society. Consequently, this becomes a shield against dictatorships or demagogies. Faced with the attacks of extremism, the dam of the law. 